\title{
Membrane-Targeting Triphenylphosphonium Functionalized Ciprofloxacin for Methicillin-Resistant Staphylococcus aureus (MRSA)
}

\author{
Sangrim Kang ${ }^{1,+}{ }^{+}$Kyoung Sunwoo ${ }^{2,+}$, Yuna Jung ${ }^{3}$, Junho K. Hur ${ }^{4}$, Ki-Ho Park ${ }^{5, *}$, \\ Jong Seung Kim ${ }^{2, *(D)}$ and Dokyoung Kim $1,3,6,7, *(\mathbb{D})$ \\ 1 Department of Anatomy and Neurobiology, College of Medicine, Kyung Hee University, Seoul 02447, Korea; \\ sangrimk@gmail.com \\ 2 Department of Chemistry, Korea University, Seoul 02841, Korea; swk9028@naver.com \\ 3 Department of Biomedical Science, Graduate School, Kyung Hee University, Seoul 02447, Korea; \\ jungpeng159@gmail.com \\ 4 Department of Genetics, College of Medicine, Hanyang University, Seoul 04763, Korea; juhur@hanyang.ac.kr \\ 5 Division of Infectious Diseases, Department of Internal Medicine, Kyung Hee University, Seoul 02447, Korea \\ 6 Center for Converging Humanities, Kyung Hee University, Seoul 02447, Korea \\ 7 Medical Research Center for Bioreaction to Reactive Oxygen Species and Biomedical Science Institute, \\ School of Medicine, Graduate School, Kyung Hee University, Seoul 02447, Korea \\ * $\quad$ Correspondence: parkkiho@khu.ac.kr (K.-H.P.); jongskim@korea.ac.kr (J.S.K.); dkim@khu.ac.kr (D.K.) \\ + These authors contributed equally to this work.
}

Academic Editor: Julien Tailhades

Received: 4 October 2020; Accepted: 28 October 2020; Published: 30 October 2020

\begin{abstract}
Multidrug-resistant (MDR) bacteria have become a severe problem for public health Developing new antibiotics for MDR bacteria is difficult, from inception to the clinically approved stage. Here, we have used a new approach, modification of an antibiotic, ciprofloxacin (CFX), with triphenylphosphonium (TPP, $\left.\mathrm{PPh}_{3}\right)$ moiety via ester- (CFX-ester- $\left.\mathrm{PPh}_{3}\right)$ and amide-coupling $\left(\mathrm{CFX}\right.$-amide- $\left.\mathrm{PPh}_{3}\right)$ to target bacterial membranes. In this study, we have evaluated the antibacterial activities of CFX and its derivatives against 16 species of bacteria, including MDR bacteria, using minimum inhibitory concentration (MIC) assay, morphological monitoring, and expression of resistance-related genes. TPP-conjugated CFX, CFX-ester-PPh ${ }_{3}$, and CFX-amide- $\mathrm{PPh}_{3}$ showed significantly improved antibacterial activity against Gram-positive bacteria, Staphylococcus aureus, including MDR S. aureus (methicillin-resistant S. aureus (MRSA)) strains. The MRSA ST5 5016 strain showed high antibacterial activity, with MIC values of $11.12 \mu \mathrm{g} / \mathrm{mL}$ for CFX-ester-PPh 3 and $2.78 \mu \mathrm{g} / \mathrm{mL}$ for CFX-amide- $\mathrm{PPh}_{3}$. The CFX derivatives inhibited biofilm formation in MRSA by more than $74.9 \%$ of CFX-amide- $\mathrm{PPh}_{3}$. In the sub-MIC, CFX derivatives induced significant morphological changes in MRSA, including irregular deformation and membrane disruption, accompanied by a decrease in the level of resistance-related gene expression. With these promising results, this method is very likely to combat MDR bacteria through a simple TPP moiety modification of known antibiotics, which can be readily prepared at clinical sites.
\end{abstract}

Keywords: antibiotic conjugates; ciprofloxacin; multidrug resistance bacteria; triphenyl-phosphonium

\section{Introduction}

Antimicrobial resistance is considered to be one of the greatest threats to human health worldwide. Widespread abuse and misuse of antibiotics has led to the emergence of antibiotic resistant bacteria [1,2]. Microbes resistant to multiple anti-microbials are known as multidrug-resistant (MDR) and cannot be easily killed using the current drugs. The MDR bacterial strains include the 
"ESKAPE" pathogens-Enterococcus faecium, Staphylococcus aureus, Klebsiella pneumoniae, Acinetobacter baumannii, Pseudomonas aeruginosa, and Enterobacter spp. The ESKAPE pathogens play a critical role in nosocomial infections and resist antimicrobial agents through drug resistance mechanisms [3]. As a result, patients infected with MDR bacteria are harder to treat, thereby increasing medical costs exorbitantly, in comparison to patients infected with bacteria more susceptible to drugs [4]. To date, many approaches have been proposed to overcome MDR bacteria, including ESKAPE pathogens, such as use of drug combination, drug modification, and drug delivery systems [5]. Many new antimicrobial agents, such as inhibitors of quorum sensing (QS) [6], antimicrobial peptides (AMPs) [7], and bacteriophages [8], have been suggested, and they are based on the target of the molecular mechanisms of MDR. In addition, various approaches based on inhibiting the formation of the negatively charged membrane bilayer, using cationic polymers and inhibitory integral proteins, similar to membrane bound multidrug efflux pumps, have been shown to be effective against both Gram-negative and Gram-positive MDR bacteria. However, these methods have proven to be difficult to develop into an approved clinical medicine $[9,10]$.

In this study, we disclosed a strategy to overcome problems associated with traditional approaches against MDR bacteria, which utilize (i) triphenylphosphonium (TPP, $\mathrm{PPh}_{3}$ ) moiety and (ii) ciprofloxacin (CFX). (i) TPP: Positively charged TPP has been widely used for targeting negatively charged sub-cellular organelles, such as mitochondria (Figure 1a). Mitochondria-targeted cell imaging and mitochondria-related biostudy, achieved by introducing TPP into the fluorophore, are widely used techniques. Moreover, tagging TPP to an anticancer drug has shown enhanced mitochondria-targeted chemo-therapeutic efficiency [11-13]. TPP-conjugated compounds have significant antibacterial activity against both Gram-negative and Gram-positive bacteria, due to the large hydrophobic surface area and delocalized charge distribution of TPP, which allows them to easily cross biological membranes [14]. (ii) CFX: CFX has been widely used for treating various bacterial infections, such as urinary tract infections, acute sinusitis, and chronic bacterial prostatitis [15]. CFX is a fluoroquinolone antibiotic that is effective against both Gram-negative and Gram-positive bacteria. CFX interferes with bacterial DNA replication and transcription by inhibiting bacterial DNA gyrase, topoisomerase II, and DNA topoisomerase IV. Traditionally, CFX has been used for treating severe infections caused by $S$. aureus. However, over a period of time, $S$. aureus and isolates of methicillin-resistant $S$. aureus (MRSA) have become resistant towards CFX and other fluoroquinolone antibiotics [16,17]. Two different mechanisms are known to lead to resistance to fluoroquinolones, including CFX, (i) by decreasing the affinity of CFX via mutations occurring in the quinolone-resistance-determining region of topoisomerase IV and DNA gyrase and (ii) by inhibiting the efflux pumps, which is less recognized (Figure 1b) [18].

Given the similarities between the mitochondrial and bacterial membranes, we have developed two derivatives of TPP-conjugated CFX, one has an ester bond (CFX-ester- $\left.\mathrm{PPh}_{3}\right)$ and the other has an amide bond (CFX-amide- $\mathrm{PPh}_{3}$ ) to increase the antibacterial activities of CFX by targeting the bacterial membrane (Figure 1c). We systematically examined the antimicrobial activities of TPP-conjugated CFX against 16 types of ESKAPE bacteria, including strains of MDR bacteria (Table 1). TPP-conjugated CFXs were found to be significantly effective against Gram-positive bacteria, S. aureus and MRSA by disrupting the cell membrane and inhibiting the multidrug efflux pump (Figure 1b). This study has successfully demonstrated the efficiency of the TPP-CFX hybridization approach for combating MDR bacteria. 


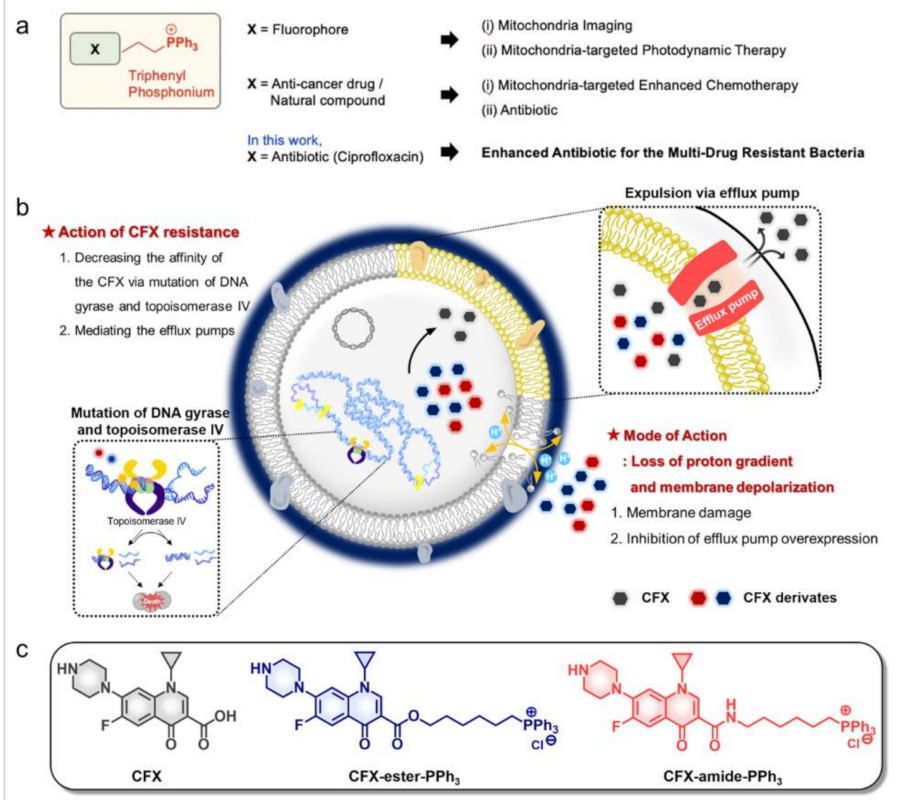

Figure 1. Schematic summary of the approach used and the motivation for this work. (a) Applications of triphenylphosphonium $\left(\mathrm{TPP}^{+}, \mathrm{PPh}_{3}\right.$ ). In this work: $\mathrm{X}=$ antibiotic (ciprofloxacin) used to enhance the effect of antibiotics against multidrug-resistant (MDR) bacteria. (b) A schematic diagram showing the mechanism of drug-resistance in bacteria and the mode of action towards ciprofloxacin (CFX) and the functioning mechanism of $\mathrm{CFX}-\mathrm{PPh}_{3}$ derivatives. (c) Chemical structure of $\mathrm{CFX}$ and its derivatives; $\mathrm{CFX}$-ester-PPh 3 , CFX-amide-PPh .

Table 1. A list of bacterial strains used in this study. Control: drug-sensitive strains.

\begin{tabular}{|c|c|c|}
\hline Species & Strains & Drug Sensitive or Resistant Bacteria \\
\hline \multicolumn{3}{|c|}{ Gram-negative } \\
\hline Escherichia coli & $\begin{array}{l}\text { ATCC }^{\circledR} 25922 \\
\text { AMCEC } 22365\end{array}$ & $\begin{array}{c}\text { Carbapenem-susceptible E. coli } \\
\text { Carbapenem-resistant E. coli (NDM-1 type) }\end{array}$ \\
\hline Klebsiella pneumoniae & $\begin{array}{l}\text { ATCC }^{\circledR} 13883 \\
\text { AMCKP } 24272\end{array}$ & $\begin{array}{c}\text { Carbapenem-susceptible K. pneumoniae } \\
\text { Carbapenem-resistant K. pneumoniae (KPC type) }\end{array}$ \\
\hline Pseudomonas aeruginosa & $\begin{array}{l}\text { ATCC }^{\circledR} 27853 \\
\text { CCARM } 2321\end{array}$ & $\begin{array}{l}\text { Carbapenem-susceptible P. aeruginosa (CSPA) } \\
\text { Carbapenem-resistant P. aeruginosa (CRPA) }\end{array}$ \\
\hline Acinetobacter baumannii & $\begin{array}{l}\text { ATCC }^{\circledR} 19606 \\
\text { AMCAB } 643\end{array}$ & $\begin{array}{c}\text { Carbapenem-susceptible } A \text {. baumannii (CSAB) } \\
\text { Carbapenem-resistant } A \text {. baumannii (CRAB) }\end{array}$ \\
\hline \multicolumn{3}{|c|}{ Gram-positive } \\
\hline Enterococcus faecium & $\begin{array}{l}\text { ATCC }^{\circledR} 29212 \\
\text { CCARM } 5024\end{array}$ & $\begin{array}{l}\text { Vancomycin-susceptible E. faecium (VSE) } \\
\text { Vancomycin-resistant E. faecium (VRE) }\end{array}$ \\
\hline Staphylococcus aureus & $\begin{array}{l}\text { ATCC }{ }^{\circledR} 29213 \\
\text { AMCSA } 5016 \\
\text { AMCSA } 5013 \\
\text { AMCSA } 3416 \\
\text { ATCC }^{\circledR} 700698 \\
\text { ATCC }^{\circledR} 700699\end{array}$ & $\begin{array}{c}\text { Methicillin-susceptible S. aureus (MSSA) } \\
\text { Methicillin-resistant S. aureus (MRSA, ST5) } \\
\text { MRSA (ST72) } \\
\text { MRSA (ST239) } \\
\text { Heterogeneous VISA (hVISA) } \\
\text { Vancomycin intermediate-resistant S. aureus (VISA) }\end{array}$ \\
\hline
\end{tabular}

\section{Results and Discussion}

\subsection{Rational}

One of the new strategies to overcome MDR bacteria is to develop membrane-active antibacterial agents. Such agents have an antibacterial action as follows: (i) to cause collapsing of the membrane 
architecture by interacting with a lipophilic moiety on the bacterial membrane, (ii) to make complex and/or localization into membrane-embedded proteins, and (iii) to alter the proton motive force (PMF) [19]. We focused on the two mechanisms of action, first is the alteration of PMF, which affects the operation system of proton-dependent multidrug efflux system, and the other is collapsing the bacterial membrane. We used the CFX as a traditional antibiotic in this study. As we described above, the resistance mechanism of CFX is that CFX binds to DNA gyrase and topoisomerase II/IV for inhibition of DNA replication and transcription. It appears to occur both by mutation of DNA gyrase and topoisomerase II/IV and by alteration of CFX permeation via the cell membrane. Thus, we designed TPP-conjugated CFX derivatives to target anionic lipids of the bacterial membrane (Figure 1b). It is known that the covalently linked TPP moiety enhances the lipophilic character of TPP-conjugated CFXs derivatives, and this strategy has been used to increase the solubility of drugs and imaging agents, and improve their bioactivity [12,20]. The TPP moiety was conjugated on the carboxylic acid moiety of CFX via esterification (for $\mathrm{CFX}$-ester- $\mathrm{PPh}_{3}$ ) and amide coupling (for $\mathrm{CFX}$-amide- $\mathrm{PPh}_{3}$ ) using triphenyl-phosphonium propyl alcohol, and triphenyl-phosphonium propyl amine, respectively. The derivatives were prepared using the protocol developed by our group (previous work: drug repositioning of antibiotic for anticancer) (Scheme S1 and S2 in Supplementary material) [21]. CFX-ester-PPh 3 was prepared by using $t$-butyloxycarbonyl (Boc)-protected CFX and triphenyl-phosphonium propyl alcohol, with potassium carbonate $\left(\mathrm{K}_{2} \mathrm{CO}_{3}\right)$ in $N$,N-dimethylformamide (DMF). The reaction mixture was stirred at $50{ }^{\circ} \mathrm{C}$ for overnight, then purified by column chromatography (yield: 82\%). The deprotection of the Boc group was carried out in an acidic condition (yield: $90 \%$ ). $\mathrm{CFX}$-amide- $\mathrm{PPh}_{3}$ was prepared in a similar way by amide coupling, using the Boc-protected CFX and triphenyl-phosphonium propyl amine with 1-ethyl-3-(3-dimethylaminopropyl) carbodiimide (EDC) and 4-dimethylaminopyridine (DMAP) catalyst in DMF. The reaction mixture was stirred at room temperature overnight and purified by silica-gel column chromatography (yield: 78\%). Thereafter, deprotection of the Boc group was carried out in an acidic condition (yield: 93\%). The purity of the synthesized compounds was verified by proton/carbon nuclear magnetic resonance $\left({ }^{1} \mathrm{H} /{ }^{13} \mathrm{C}-\mathrm{NMR}\right)$ and electrospray ionization mass spectrometry.

\subsection{MIC Assay}

Antibacterial activity of TPP-conjugated CFX derivatives was evaluated against 16 types of Gram-positive and Gram-negative bacterial strains, including MDR bacteria (Table 1). Non-derivatized $\mathrm{CFX}$ was used as a control to compare the activities of the CFX-PPh 3 derivatives. The minimum inhibitory concentration (MIC) values of CFX for all types of strains were produced with reference to the Clinical and Laboratory Standards Institute (CLSI) recommended breakpoints (Table 2) [22]. MIC assays of CFX and $\mathrm{CFX}-\mathrm{PPh}_{3}$ derivatives against bacteria strains (16 types) were performed using the broth micro-dilution method in a 96-well plate and represented in Figure S1 (Supplementary Material).

As shown in Figure 2a and Table 2, CFX-ester- $\mathrm{PPh}_{3}$ and $\mathrm{CFX}$-amide- $\mathrm{PPh}_{3}$ showed significant inhibition of bacterial growth at a low concentration range $(1.39-89.02 \mu \mathrm{g} / \mathrm{mL})$ for Gram-positive S. aureus and MRSA, both TPP-conjugated CFXs showed better antibacterial activity against sensitive and resistant strains of Gram-positive bacteria than for Gram-negative bacteria. CFX-amide-PPh, in particular, showed excellent antibacterial activity against two strains of MRSA 5016 and 5013 (MIC value $=2.78$ and $1.39 \mu \mathrm{g} / \mathrm{mL}$, respectively). For the MRSA 3416 strain, slightly lower antibacterial activity was observed with MIC values for CFX-ester-PPh 3 and CFX-amide-PPh 3 being 89.02 and $22.25 \mu \mathrm{g} / \mathrm{mL}$, respectively. Interestingly, the MRSA ST5 5016 strain showed resistance towards CFX with an MIC value of $128 \mu \mathrm{g} / \mathrm{mL}$. However, it showed high sensitivity towards CFX-amide-PPh 3 and CFX-ester-PPh 3 with a relatively low MIC value of $2.78 \mu \mathrm{g} / \mathrm{mL}$ and $11.12 \mu \mathrm{g} / \mathrm{mL}$ (Figure 2a and Table 2), respectively. Similarly, vancomycin intermediate-resistant S. aureus (VISA) and heterogeneous VISA (hVISA) had high MIC values with CFX $(64.0 \mu \mathrm{g} / \mathrm{mL})$; however, hVISA showed a slightly lower MIC value of $11.12 \mu \mathrm{g} / \mathrm{mL}$ when treated with $\mathrm{CFX}$-ester-PPh $\mathrm{P}_{3}$ and $\mathrm{CFX}$-amide-PPh . For VISA, treatment with $\mathrm{CFX}$-amide-PPh showed a lower value of $11.12 \mu \mathrm{g} / \mathrm{mL}$; however, after treatment with CFX-ester-PPh, 
it showed a higher value of $44.51 \mu \mathrm{g} / \mathrm{mL}$. From these data, we confirmed that TPP-modified CFXs showed a higher antibacterial activity against MRSA; moreover, $\mathrm{CFX}$-amide- $\mathrm{PPh}_{3}$ performed better than CFX-ester-PPh ${ }_{3}$ and CFX. As shown in Table 2, CFX derivatives (especially CFX-amide- $\mathrm{PPh}_{3}$ ) showed excellent antibacterial activity against MDR strains compared to original CFX. However, it showed slightly reduced antibacterial activity (high MIC values) against drug-sensitive strains, and this is probably due to the chemical modification of carboxylic acid within CFX and its mode of action changes. From these results, we understand that our chemical conjugation approach on the carboxylic acid within CFX might be promising against MDR bacteria rather than drug-sensitive bacteria. To confirm the synergetic effect of TPP moiety and CFX in a single molecule, we conducted an additional experiment within the MRSA 5016 strain: antibiotic property analysis of (i) heptyltriphenylphosphonium bromide (TPP) only, (ii) scramble of TPP and CFX, (iii) CFX only, (iv) CFX-ester- $\mathrm{PPh}_{3}$, and (v) CFX-amide- $\mathrm{PPh}_{3}$ (Figure S2a). In this experiment, the set of "TPP only" showed no antibiotic effect against MRSA 5016 strain. No significant antibiotic effect was also observed in the sets of CFX only and the scramble of TPP with CFX (above $65 \mu \mathrm{g} / \mathrm{mL}$ ). In the case of TPP-conjugated CFX derivatives, lower MIC values of $11.12 \mu \mathrm{g} / \mathrm{mL}$ and $2.56 \mu \mathrm{g} / \mathrm{mL}$ were observed for the CFX-ester-PPh ${ }_{3}$ and CFX-amide- $\mathrm{PPh}_{3}$, respectively. These results represent that the hybrid of TPP moiety and CFX in a single molecule gave a synergetic antibiotic effect in terms of large hydrophobic surface area and delocalized charge distribution of TPP, alter the proton motive force, and regulation of the CFX-related gene expression.

Table 2. Minimum inhibitory concentration values and inhibitory concentration for biofilm formation against Enterococcus faecium, Staphylococcus aureus, Klebsiella pneumoniae, Acinetobacter baumannii, Pseudomonas aeruginosa, and Enterobacter spp. (ESKAPE) pathogens (a total of 16 types), including MDR bacteria, against $\mathrm{CFX}$ and $\mathrm{CFX}-\mathrm{PPh}_{3}$ derivatives. * The biofilm inhibition rate was calculated using the biofilm biomass in bacteria treated with the compounds. Control (untreated strain): biofilm biomass in untreated bacteria. Units: $\mu \mathrm{g} / \mathrm{mL}$. The minimum inhibitory concentration (MIC) values refer to the Clinical and Laboratory Standards Institute, 2016 (CLSI) guidelines.

\begin{tabular}{|c|c|c|c|c|c|c|c|c|}
\hline \multirow[b]{2}{*}{ Type or Strain } & \multirow{2}{*}{$\begin{array}{c}\text { CLSI } \\
\text { Breakpoint } \\
(\mu \mathrm{g} / \mathrm{mL})\end{array}$} & \multirow[b]{2}{*}{ QC Range } & \multicolumn{3}{|c|}{$\operatorname{MIC}(\mu \mathrm{g} / \mathrm{mL})$} & \multicolumn{3}{|c|}{ Biofilm Inhibition Rate (\%) * } \\
\hline & & & CFX & $\begin{array}{c}\text { CFX- } \\
\text { Ester-PPh }\end{array}$ & $\begin{array}{c}\text { CFX- } \\
\text { Amide-PPh }\end{array}$ & CFX & $\begin{array}{c}\text { CFX- } \\
\text { Ester-PPh }\end{array}$ & $\begin{array}{c}\text { CFX- } \\
\text { Amide-PPh }\end{array}$ \\
\hline \multicolumn{9}{|c|}{ Gram-negative Bacteria } \\
\hline E. coli & $\leq 1$ & $0.004-0.015$ & 0.004 & 5.56 & 5.56 & $\begin{array}{c}<0.5 \\
(96.49 \%)\end{array}$ & $\begin{array}{c}32 \\
(76.0 \%)\end{array}$ & $\begin{array}{c}8 \\
(85.4 \%)\end{array}$ \\
\hline NDM-1 type & $\leq 1$ & - & 16 & $>178.05$ & 89.02 & - & - & - \\
\hline K. pneumoniae & $\leq 1$ & - & 0.031 & 22.25 & 44.51 & - & - & - \\
\hline KPC type & $\leq 1$ & - & 32 & $>178.05$ & 178.05 & $\begin{array}{c}128 \\
(74.8 \%)\end{array}$ & $\begin{array}{c}>512 \\
(28.5 \%)\end{array}$ & $\begin{array}{c}256 \\
(51.2 \%)\end{array}$ \\
\hline P. aeruginosa & $\leq 1$ & - & $0.25-0.125$ & 89.02 & 89.02 & $\begin{array}{c}2 \\
(73.2 \%)\end{array}$ & $\begin{array}{c}64 \\
(50.1 \%)\end{array}$ & $\begin{array}{c}256 \\
(54.0 \%)\end{array}$ \\
\hline CRPA & $\leq 1$ & $0.25-2.0$ & 32 & $>178.05$ & 178.05 & $\begin{array}{c}<0.5 \\
(80.3 \%)\end{array}$ & $\begin{array}{c}64 \\
(74.4 \%)\end{array}$ & $\begin{array}{c}32 \\
(56.5 \%)\end{array}$ \\
\hline A. baumannii & $\leq 1$ & & 0.5 & 89.02 & 89.02 & $\begin{array}{c}256 \\
(66.0 \%)\end{array}$ & $\begin{array}{c}>512 \\
(48.2 \%)\end{array}$ & $\begin{array}{c}256 \\
(53.4 \%)\end{array}$ \\
\hline CRAB & $\leq 1$ & & 64 & 89.02 & 89.02 & - & - & - \\
\hline \multicolumn{9}{|c|}{ Gram-positive Bacteria } \\
\hline E. faecium & $\leq 1$ & $0.25-2.0$ & $1.0-0.5$ & 178.05 & 44.51 & $\begin{array}{c}<0.5 \\
(65.0 \%)\end{array}$ & $64(60.0 \%)$ & $\begin{array}{c}64 \\
(91.5 \%)\end{array}$ \\
\hline VRE & $\leq 1$ & - & 256 & 89.02 & 22.25 & - & - & - \\
\hline S. aureus & $\leq 1$ & $0.12-0.5$ & 0.5 & 22.25 & 2.78 & $\begin{array}{c}<0.5 \\
(89.49 \%)\end{array}$ & $\begin{array}{c}16 \\
(48.9 \%)\end{array}$ & $\begin{array}{c}4 \\
(73.6 \%)\end{array}$ \\
\hline MRSA 5016 & $\leq 1$ & & 128 & 11.12 & 2.78 & $\begin{array}{c}128 \\
(54.1 \%)\end{array}$ & $\begin{array}{c}8 \\
(43.9 \%)\end{array}$ & $\begin{array}{c}4 \\
(74.9 \%)\end{array}$ \\
\hline MRSA 5013 & $\leq 1$ & & 0.5 & 11.12 & 1.39 & $\begin{array}{c}<0.5 \\
(88.1 \%)\end{array}$ & $\begin{array}{c}8 \\
(57.2 \%)\end{array}$ & $\begin{array}{c}4 \\
(75.2 \%)\end{array}$ \\
\hline MRSA 3416 & $\leq 1$ & & 64 & 89.02 & 22.25 & $\begin{array}{c}64 \\
(60.2 \%)\end{array}$ & $\begin{array}{c}64 \\
(88.2 \%)\end{array}$ & $\begin{array}{c}32 \\
(72.5 \%)\end{array}$ \\
\hline hVISA & $\leq 1$ & & 64 & 11.12 & 11.12 & - & - & - \\
\hline VISA & $\leq 1$ & & 64 & 44.51 & 11.12 & - & - & - \\
\hline
\end{tabular}



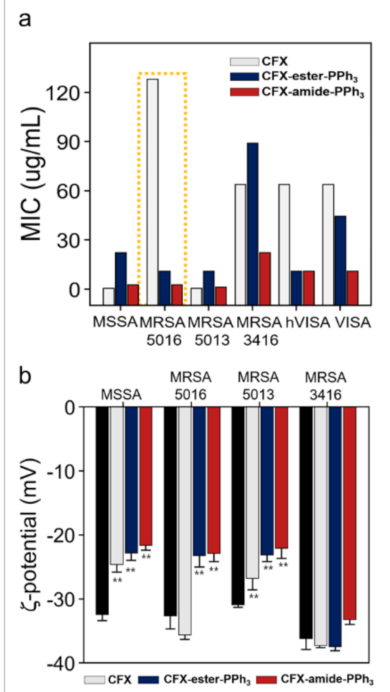

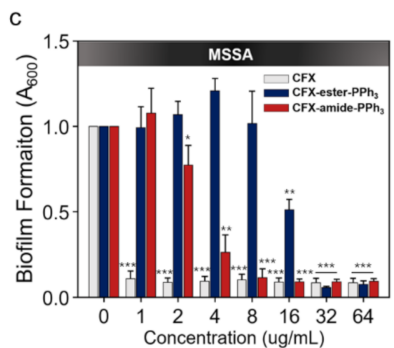

d

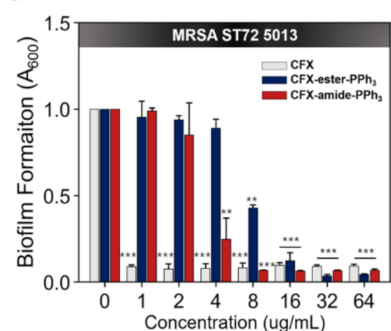

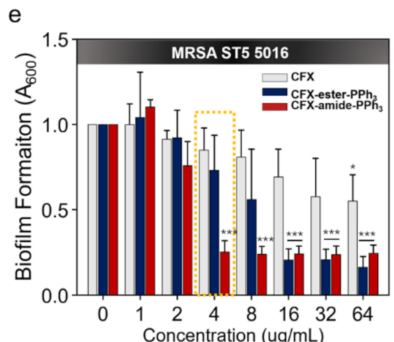

f

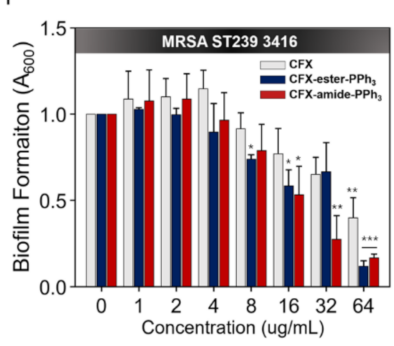

Figure 2. Minimum inhibitory concentration (MIC) and biofilm formation assay for CFX, CFX-ester-PPh and CFX-amide- $\mathrm{PPh}_{3}$ against methicillin-susceptible S. aureus (MSSA) and MDR Staphylococcus aureus strains. (a) MIC values for different compounds with MSSA and five types of MDR S. aureus. $\mathrm{CFX}, \mathrm{CFX}$-ester- $\mathrm{PPh}_{3}$ and $\mathrm{CFX}$-amide- $\mathrm{PPh}_{3}$ were serially diluted two-fold in a 96-well microplate according to the concentration range: $\mathrm{CFX}$ at $512-0.00005 \mu \mathrm{g} / \mathrm{mL} ; \mathrm{CFX}$-ester-PPh 3 and CFX-amide-PPh at $178.5-1.39 \mu \mathrm{g} / \mathrm{mL}$. (b) Zeta potential of MSSA and methicillin-resistant S. aureus (MRSA) strains. Zeta-potential was measured at $25^{\circ} \mathrm{C}$ and determined using phase analysis of scattered light by colloidal particles suspended in de-ionized water $\left(\mathrm{DI} \mathrm{H}_{2} \mathrm{O}\right)$. ( $\left.\mathbf{c}-\mathbf{f}\right)$ Inhibitory activity against biofilm formation depending on concentration of CFX, CFX-ester- $\mathrm{PPh}_{3}$, and CFX-amide-PPh 3 . Biofilm formed by MSSA and MRSA strains was stained with crystal violet for $10 \mathrm{~min}$ and eluted in $33 \%$ acetic acid. The biofilm mass was measured at $600 \mathrm{~nm}$ of optical density $(\mathrm{OD})$ values. The yellow triangle indicates maximum inhibition of biofilm formation with $\mathrm{CFX}$-amide- $\mathrm{PPh}_{3}$ against the MRSA strains. All compound treated bacteria were statistically calculated compared to the compound untreated group (as a control). The data for the inhibition of biofilm formation in Gram-negative bacteria are represented in Supporting Information (Figure S6). All experiments were repeated three times. The results are shown as the means \pm standard deviation of triplicate independent experiments $\left({ }^{*} p<0.05,{ }^{* *} p<0.001,{ }^{* * *} p<0.0001\right)$.

For strains of Gram-negative MDR bacteria, such as carbapenem-resistant E. coli (CRE NDM-1 type), carbapenem-resistant K. pneumoniae (CRE KPC type), carbapenem-resistant A. baumannii (CRAB), and carbapenem-resistant $P$. aeruginosa (CRPA), however, both of the modified CFXs showed no significant antibacterial activity at a concentration $\geq 178.05 \mu \mathrm{g} / \mathrm{mL}$ (Table 2 and Figure S2b). These data suggest that CFX, modified with TPP moiety, possesses excellent antibacterial activity against Gram-positive bacteria, especially MSSA and MRSA strains. The selectivity for Gram-positive bacteria is expected because of the presence of the bacterial outer membrane $(\mathrm{OM})$, which exists only in Gram-negative bacteria. The OM in Gram-negative bacteria is impermeable to toxic molecules, such as antimicrobial compounds, depending on their molecular weight (MW), and shows limited diffusion of hydrophobic substances via lipopolysaccharide (LPS) on the OM [23,24]. O'Shea and Moser have reported that the cell envelope of Gram-negative bacteria does not allow molecules larger $600 \mathrm{Da}$ to pass through. Large antibiotics, such as vancomycin and daptomycin ( MW of 1,400 Da), cannot penetrate the OM of Gram-negative bacteria. Therefore, a large hydrophobic surface with high lipophilicity and delocalized charge distribution, such as TPP, and high MW CFX-derivatives ( 700 Da) affect the permeability of TPP-conjugated CFXs through the OM layers, these factors could explain the ineffective activity against Gram-negative bacteria $[25,26]$. 


\subsection{Cytotoxicity Assay}

In our previous work, the low toxicity of CFX derivatives was verified within various cell lines, including human fibroblast cell line (BJ) and non-tumorigenic breast epithelial cell line (MCF 10A) [21]. According to the report, the $\mathrm{CFX}$-ester- $\mathrm{PPh}_{3}$ showed the half maximal inhibitory concentration $\left(\mathrm{IC}_{50}\right)$ value as $631.82 \mu \mathrm{M}$ toward BJ cell, and $>1000 \mu \mathrm{M}$ for MCF 10A cell, respectively, and these results represent the negligible toxicity of CFX derivatives against normal cells. We additionally performed the hemolysis assay against mouse red blood cells (RBCs) to confirm the effect of the CFX and CFX derivatives toward the hemolysis of MSSA (Figure S3). The non-treated control group (only bacteria) showed the hemolysis of RBCs, approximately $50 \%$, compared with the positive control group (treatment $0.1 \%$ of Triton-X 100). In contrast, the compounds-treated groups showed the significantly inhibited hemolysis of RBCs at $2 \times$ MIC to less than $2 \%$. In the case of the CFX, the dose-dependent hemolysis of RBCs in MSSA was observed when compared with the non-treated control group. From the results, we confirmed that the CFX-derivatives significantly affect the RBCs hemolysis activity of MSSA.

\subsection{Membrane-Potential Analysis}

As the CFX-derivatives are conjugated with the lipophilic, cationic $\mathrm{PPh}_{3}$ moiety, they can rapidly access the negatively charged phospholipid bilayer of the bacterial membrane. We assumed that the membrane-potential of bacterial strains could be increased by the $\mathrm{PPh}_{3}$ moiety. To evaluate change in electric charge on the bacterial surface, we measured the zeta-potential of MSSA and MRSA strains. Figure $2 \mathrm{~b}$ shows the zeta-potential of MSSA and MRSA strains treated with or without CFX and the two CFX-derivatives. The average zeta-potential value of MSSA (no treatment control) was found to be $-32.4 \mathrm{mV} \pm 0.95$, indicating a negative membrane charge. In the case of MSSA, treatment with CFX, CFX-ester- $\mathrm{PPh}_{3}$, and CFX-amide- $\mathrm{PPh}_{3}$ significantly increased zeta-potential values to $-24.6 \mathrm{mV} \pm 1.32,-22.8 \mathrm{mV} \pm 1.93$, and $-21.7 \mathrm{mV} \pm 1.18$, respectively. The zeta-potentials for MRSA strains (5016, 5013, and 3416, no treatment control) were found to be $-32.7 \mathrm{mV} \pm 1.75$, $-30.9 \mathrm{mV} \pm 0.35$, and $-36.2 \mathrm{mV} \pm 1.60$, respectively. The zeta-potential for MRSA 5016 strain, treated with CFX alone, was found to be slightly decreased at $-35.6 \mathrm{mV} \pm 0.88$ compared to that for the untreated control group; however, in CFX-ester- $\mathrm{PPh}_{3}$ and $\mathrm{CFX}$-amide- $\mathrm{PPh}_{3}$ treatment groups, MRSA 5016 showed a significantly increased zeta-potential at $-23.2 \mathrm{mV} \pm 1.80$ and $-22.1 \mathrm{mV}$ \pm 1.60 , respectively. The zeta-potential of MRSA 5013 increased significantly to $-26.6 \mathrm{mV} \pm 1.88$, $-23.1 \mathrm{mV} \pm 0.97$, and $-22.1 \mathrm{mV} \pm 1.60$, respectively, for $\mathrm{CFX}, \mathrm{CFX}$-ester-PPh , and $\mathrm{CFX}$-amide- $\mathrm{PPh}_{3}$ treatment groups. For MRSA 3416 strain, the zeta-potential increased slightly to $-33.2 \mathrm{mV} \pm 0.68$ only in the CFX-amide- $\mathrm{PPh}_{3}$ treatment group. We monitored the membrane activity mechanism of actions of CFX derivatives by fluorescence spectroscopy analysis. We used a cationic membrane potential-sensitive fluorescence probe, 3,3'-Dipropylthia-dicarbocyanine iodide $\left(\mathrm{DiSC}_{3}\right)$ [27], to monitor the depolarization of the bacteria (MSSA, MRSA) membrane. The fluorescence of $\mathrm{DiSC}_{3}$ is increased when it is released into the medium due to the bacteria membrane disruption. We observed that the fluorescence intensity of $\mathrm{DiSC}_{3}$ was dramatically increased after treatment of CFX derivatives at the 2.0 $\times$ and $4.0 \times$ MIC (Figure S4), while the CFX-treated group had no increment of fluorescence at any concentration. Thus, the cationic character of $\mathrm{PPh}_{3}$ modified CFX derivatives might have more interactions with the negatively charged bacterial membrane, shifting the membrane potential towards neutral. This could contribute to the destabilization of the bacterial membrane [28].

\subsection{Crystal Violet Assay}

We examined the antibiofilm activities of CFX and $\mathrm{CFX}-\mathrm{PPh}_{3}$ derivatives against 16 species of Gram-negative and Gram-positive bacteria. Similar to the MIC results, CFX-ester- $\mathrm{PPh}_{3}$ and $\mathrm{CFX}$-amide- $\mathrm{PPh}_{3}$ significantly inhibited biofilm formation in Gram-positive bacteria compared to that in Gram-negative bacteria (Figure $2 \mathrm{c}-\mathrm{f}$ and Table 2). As shown in Figure $2 \mathrm{c}-\mathrm{f}$, biofilm formation of 
CFX-treated MSSA was inhibited by more than $90 \%$ at all concentrations $(0.5-256 \mu \mathrm{g} / \mathrm{mL})$. Compared to CFX alone, $\mathrm{CFX}-\mathrm{PPh}_{3}$ derivatives showed a slightly lower inhibitory activity against biofilm formation, $48.9 \%$ and $73.6 \%$ at $16 \mu \mathrm{g} / \mathrm{mL}$ and $4 \mu \mathrm{g} / \mathrm{mL}$, respectively. Further, CFX showed inhibitory activity against biofilm formation, $54.1 \%$ and $60.2 \%$ at higher doses of $128 \mu \mathrm{g} / \mathrm{mL}$ and $64 \mu \mathrm{g} / \mathrm{mL}$, respectively, for MRSA 5016 and 3416 strains. For MRSA 5013 strain, 89.5\% inhibitory activity of CFX at $0.5 \mu \mathrm{g} / \mathrm{mL}$ was seen. However, the CFX-amide- $\mathrm{PPh}_{3}$ showed excellent inhibitory activity against biofilm formation compared to CFX. The biofilm formation by MRSA 5016 was inhibited to $73.6 \%$ by $4 \mu \mathrm{g} / \mathrm{mL} \mathrm{CFX-amide-PPh}$ and to $93.3 \%$ by $8 \mu \mathrm{g} / \mathrm{mL}$ CFX-amide-PPh . For MRSA 5013 strain, $\mathrm{CFX}$ and $\mathrm{CFX}-\mathrm{PPh}_{3}$ derivatives showed antibiofilm activity, $88.1 \%$ at $0.5 \mu \mathrm{g} / \mathrm{mL}$ (CFX), $57.2 \%$ at $8 \mu \mathrm{g} / \mathrm{mL}$ (CFX-ester-PPh 3 ), and $75.2 \%$ at $4 \mu \mathrm{g} / \mathrm{mL}(\mathrm{CFX}$-amide-PPh 3 ) (Figure 2c-f and Table 2). Next, we evaluated the compound's inhibition property of biofilm formation at the sub-MICs (listed in Table 3) against MSSA and MRSA 5016. The results show that the CFX and CFX-PPh 3 derivatives effectively inhibited the biofilm formation at $1 / 2$ sub-MIC of MSSA by more than $80 \%$. The biofilm formation in MRSA was inhibited by sub-MIC of CFX or CFX-amide- $\mathrm{PPh}_{3}$ more than $40 \%$. The CFX-ester- $\mathrm{PPh}_{3}$ slightly inhibited biofilm formation at $1 / 2$ sub-MIC of MRSA to $26.7 \%$ (Figure S5a, Table S2). Additionally, we conducted the biofilm assay to confirm whether the CFX derivatives have any ability to disrupt the preformed bacterial biofilm or not. The results show that the CFX derivatives could disrupt the biofilm of MSSA and MRSA, approximately $20 \%$, at higher concentrations of $32 \mu \mathrm{g} / \mathrm{mL}$ and $64 \mu \mathrm{g} / \mathrm{mL}$, which are slightly higher concentrations than MIC (Figure S5b). Given these results, we verified the properties of CFX derivatives for inhibition of bacterial biofilm formation at sub-MIC and the preformed biofilm's disruption ability. In the case of the Gram-negative susceptible and resistant bacteria, both the TPP-modified CFXs showed no antibiofilm activity, these results correlate with the MIC results (Figure S6).

Table 3. The MIC values of CFX and CFX-PPh 3 derivatives. The values were used for the analysis of zeta-potential, time-kill assay, OD measurement, TEM imaging, and qRT-PCR analysis. Units: $\mu \mathrm{g} / \mathrm{mL}$.

\begin{tabular}{ccccccc}
\hline \multirow{2}{*}{ MIC } & \multicolumn{3}{c}{ MSSA } & \multicolumn{3}{c}{ MRSA ST5 5016 } \\
\cline { 2 - 7 } & CFX & CFX-ester-PPh & CFX-amide-PPh & CFX & CFX-ester-PPh $_{3}$ & CFX-amide-PPh \\
\hline $0.5 \times$ & 0.25 & 11.12 & 1.39 & 64 & 5.56 & 1.39 \\
$1.0 \times$ & 0.5 & 22.24 & 2.78 & 128 & 11.12 & 2.78 \\
$2.0 \times$ & 1.0 & 44.48 & 5.56 & 256 & 22.24 & 5.56 \\
$4.0 \times$ & 2.0 & 89.96 & 11.12 & 512 & 44.48 & 11.12 \\
$8.0 \times$ & 4.0 & 178 & 22.25 & 1,024 & 88.96 & 22.24 \\
\hline
\end{tabular}

\subsection{Time-Kill Assay}

Of the two derivatives, CFX-amide- $\mathrm{PPh}_{3}$ exhibited superior antibacterial activity against MDR $S$. aureus, such as the MRSA and VISA, with MIC values ranging from $1.36 \mu \mathrm{g} / \mathrm{mL}$ to $22.25 \mu \mathrm{g} / \mathrm{mL}$. In this assay, we chose the MRSA ST5 5016 strain, which is resistant towards CFX (Figure 3 and Figure S7). MSSA was used as a control. First, a time-kill assay was performed to assess the antibacterial activity of CFX and CFX-PPh ${ }_{3}$ derivatives against MSSA and MRSA ST5 5016 at different concentrations $(0.5 \times$ MIC, $1 \times$ MIC, and $2 \times$ MIC, see Methods section for the details and Table 3 for the MIC values).

After the initial inoculation of approximately $1 \times 10^{6}$ colony forming units (CFUs)/mL of MSSA and MRSA, CFX- $\mathrm{PPh}_{3}$ derivatives showed a dramatic increase in antibacterial activity within $6 \mathrm{~h}$ (Figure 3a,b). CFX-treatment was ineffective against MRSA in the concentration range of $0.5 \times$ MIC and $1 \times$ MIC within $6 \mathrm{~h}$; however, the CFX-PPh ${ }_{3}$ derivatives showed significant activity at all concentration ranges over the given time. In particular, $\mathrm{CFX}$-amide- $\mathrm{PPh}_{3}$ killed approximately $99.9 \%$ of MRSA at $2 \times$ MIC within $3 \mathrm{~h}$ and showed more than $99.9 \%$ activity at lower concentration ranges of $0.5 \times$ and $1 \times$ MIC, within $6 \mathrm{~h}$. In the case of MSSA, CFX and CFX-ester-PPh $\mathrm{P}_{3}$ treatment at $0.5 \times, 1 \times$, and $2 \times$ MIC significantly decreased the viable cell count within $6 \mathrm{~h}$. Interestingly, $\mathrm{CFX}$-amide- $\mathrm{PPh}_{3}$ treatment eliminated MSSA at $2 \times$ MIC within $3 \mathrm{~h}$. In terms of MSSA-killing rate, $\mathrm{CFX}$-amide- $\mathrm{PPh}_{3}$ was faster than $\mathrm{CFX}$-ester- $\mathrm{PPh}_{3}$. These results indicate that the TPP-modified CFX derivatives had 
high bactericidal activity (eradicating more than $99.9 \%$ ) against MSSA and MRSA at a concentration of $2 \times$ MIC. The inhibitory effects of CFX-PPh ${ }_{3}$ derivatives on the growth of MSSA and MRSA were also confirmed by growth curve measurements (Figure 3c). According to the results, CFX and CFX-PPh derivatives at $1 \times$ MIC effectively inhibited the growth of MSSA and MRSA (decreasing in CFUs $/ \mathrm{mL}$ value by approximately 100 -fold).
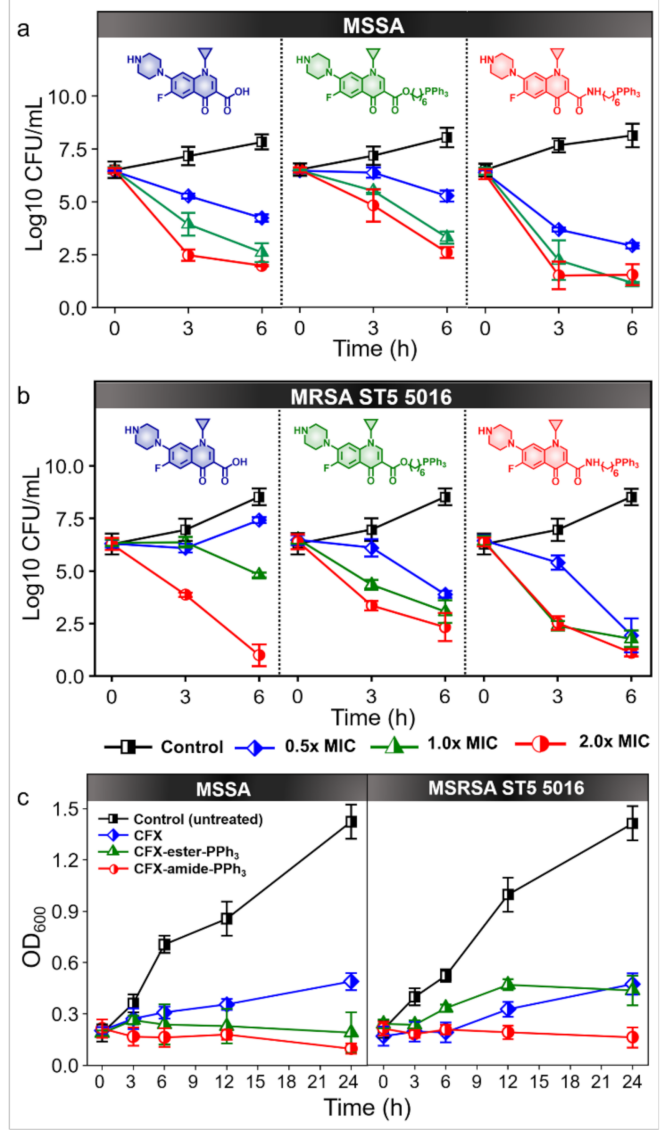

Figure 3. Time-and concentration-dependent efficacy assay for MRSA and MSSA with CFX and CFX-PPh 3 derivatives. (a,b) Time-kill assay of CFX and CFX-PPh ${ }_{3}$ derivatives against (a) MSSA and (b) MRSA. Inset A-C representative concentrations; A: $0.5 \times$ MIC, B: $1.0 \times$ MIC, C: $2.0 \times$ MIC. These data are represented as the means \pm standard deviation of three results. (c) The growth curve of MSSA and MRSA treated with CFX and CFX-PPh 3 derivatives at 1.0 $\times$ MIC of each compound. Each point represents the $\mathrm{OD}$ values at $600 \mathrm{~nm}$. All experiments were performed in three independent replicates. The $0.5 \times$ MIC, $1.0 \times$ MIC, and 2.0 $\times$ MIC values in this experiment are indicated in Table 2.

\subsection{Morphology Analysis}

From the antibacterial activity analysis and time-kill assay results, the improved properties of TPP-conjugated CFXs were verified for MDR bacteria treatment. The lipophilic and cationic property of TPP enables it to penetrate across the negatively charged membranes of MDR bacteria. To understand the mode of action, such as direct contact with the bacterial cell membrane, we first observed the morphological changes in MRSA using TEM imaging after treating the bacteria with $\mathrm{CFX}$ and CFX-PPh ${ }_{3}$ derivatives (Figure 4a). The control set of MRSA (without antibiotics) exhibited a well-defined morphology of coccus with an intact septum and smooth surface features of bacteria (red arrow in Figure 4a, A). However, the antibiotic-treated sets (CFX, CFX-PPh ${ }_{3}$ derivatives) showed significant membrane deformation, with irregular and rough surfaces (Figure 4a, B-D). CFX and CFX-derivatives treated MRSA had a thinner cell wall and the cell shape was distorted (black arrow). A thorn-like layer was present around the outer wall (green arrow). Moreover, a portion of the 
cytoplasmic membrane of MRSA was in lysis (purple arrow). These findings indicate that both the cell wall and the cytoplasmic membrane of MRSA were affected by CFX-PPh ${ }_{3}$ derivatives, resulting in the loss of cellular contents (yellow arrow) and lysis of intracellular contents (blue arrow). Notably, MRSA treated with CFX-amide-PPh 3 appeared to have a significantly damaged membrane (Figure 4a, D). We also observed some leakage of the cytoplasmic contents of bacteria to the extracellular environment, due to membrane lysis. From the TEM imaging analysis, we confirmed the working mechanism of TPP-conjugated CFXs, direct contact with the MRSA membrane and disruption of the intact morphology. According to a report by Jan Trnka et al., the lipophilic TPP moiety is capable of accumulating in a negatively charged compartment [29]. Bacterial membranes are composed of highly negatively charged phospholipids, including cardiolipin (CL) and phosphatidyl-glycerol (PG) [30]. Therefore, lipophilic and cationic TPP-modified CFXs selectively target and collapse the anionic bacterial membranes of MSSA and MRSA.

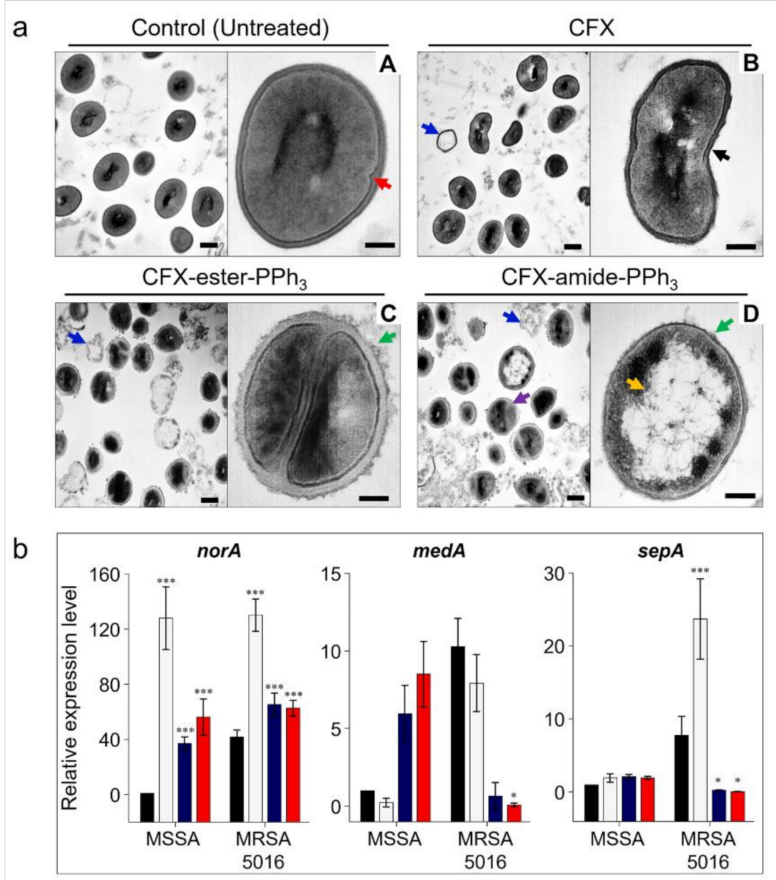

Figure 4. (a) Transmission electron microscopy (TEM) images of MRSA ST5 5016 cells treated with each compound at $0.5 \times$ MIC for $6 \mathrm{~h}$ at different magnifications. A: untreated control of MRSA ST5 5016, B: MRSA treated with 0.5× MIC of CFX, C: MRSA treated with $0.5 \times$ MIC of CFX-ester-PPh, and D: MRSA treated with $0.5 \times$ MIC of CFX-amide- $\mathrm{PPh}_{3}$. The images on the left of all micrographs indicate low-magnification TEM images (low: 40,000× and scale bar: $200 \mathrm{~nm}$ ) and on the right, high-magnification images of the indicated area (high: 100,000 $\times$ and scale bar: $100 \mathrm{~nm}$ ). Each arrow represents the following; the red arrow: intact septum, the black arrow: thinned and irregular cell wall and distortion of the cell, the green arrow: a thorn-like layer present around the outer wall, the purple arrow: partial disintegration of the cytoplasmic membrane, the yellow arrow: loss of cell contents, and the blue arrow: lysis of intracellular contents. (b) Effects of CFX and CFX-PPh 3 derivatives on the relative mRNA expression level of efflux pump genes, such as nor $A$, sep $A$, and mdeA, in MSSA and MRSA. The gene expression level was measured after $\mathrm{CFX}$ and $\mathrm{CFX}-\mathrm{PPh}_{3}$ derivative treatment at $0.5 \times \mathrm{MIC}$ in comparison to the drug-free growth used as control. Each cycle threshold $(\mathrm{Ct})$ value was normalized to $16 \mathrm{~S}$ rRNA as internal control, and the normalized fold change was calculated using the delta-delta $C t$ method, with a drug-free group being the control. Gray bar (MSSA) was assigned a value of 1 and represented the control. The results are shown as the means \pm standard deviation of triplicate independent experiments. ${ }^{*}$ Significant, $p<0.05,{ }^{* * *}$ highly significant, $p<0.0001$. 


\subsection{Gene Expression Analysis}

To understand the changes in the expression of membrane-related genes, we performed qRT-PCR analysis for the multi-efflux drug pump (MEDP)-related genes. As MEDPs use the proton motive force (PMF) to release the antibiotics, it is possible to prevent the action of MEDPs by decreasing PMF. In this study, we examined the levels of nor $A$, sep $A$, and med $A$, which are related to PMF-dependent MEDPs (Figure 4b). We observed a significant over-expression of nor A mRNA in both MSSA (127.8-fold) and MRSA (130-fold), after CFX treatment, and compared these levels to that for the untreated control. However, the mRNA expression levels of the nor $A$ were down-regulated in MSSA (CFX-ester-PPh ${ }_{3}$ : 37-fold, CFX-amide- $\mathrm{PPh}_{3}:$ 56.2-fold) and MRSA (CFX-ester-PPh $:$ 65.4-fold, CFX-amide-PPh $:$ 62.6-fold) treated with TPP-modified CFXs compared to the strains treated with CFX. In the case of sepA and medA, MSSA showed no significant changes for both CFX-PPh 3 derivatives, but MRSA showed a significantly decreased level of gene expression, sep $A\left(C F X-e s t e r-P P h_{3}\right.$ : 0.3-fold, $C F X$-amide-PPh ${ }_{3}$ : 0.1-fold), medA (CFX-ester-PPh $:$ 0.7-fold, CFX-amide-PPh 3 :0.1-fold), compared to the untreated control. As expected, CFX-treated MRSA had increased expression levels of sepA (23.7-fold) and medA (7.9-fold). A similar increase in the expression level of norA (encodes the MDR efflux pump) was observed in MRSA. As MRSA 5016 strain is resistant towards CFX, we observed an over-expression of CFX-related efflux pump genes (nor $A$, sep $A$, and medA). However, $\mathrm{CFX}-\mathrm{PPh}_{3}$ derivatives showed down-regulated levels of these genes in wild-type $S$. aureus and MDR S. aureus. According to Chang et al. (2018), $\mathrm{TPP}^{+}$-conjugated natural products show antifungal activities against Candida spp., because $\mathrm{TPP}^{+}$can bypass the drug efflux, as it is not affected by efflux pumps [31]. Based on the results, TPP moiety, due to its inhibition of drug efflux, can help to enhance antibacterial activities of CFX. Additionally, we performed the qPCR analysis of the DNA-gyrase related gene, gyrA, to confirm the DNA-gyrase inhibition ability (CFX's mode of action) of CFX derivatives [18]. We checked the mRNA expression level of the gyrA gene in MSSA by qRT-PCR, and the result shows that the expression of the gyrA gene was significantly reduced in the CFX derivatives-treated group. Given this result, it can be expected that the CFX derivatives have bacterial DNA-gyrase inhibition ability (<1-fold) similar to CFX (Figure S8).

In the reports, the tolerance acquisition towards CFX in S. aureus has shown that the MIC increases four-fold after four passages and eight-fold after eight passages [32]. Unlike these results, the CFX derivatives in our study showed no change in the MIC values until eight passages in the same experimental conditions. The CFX resistance of $S$. aureus has genetically evolved via the acquisition of mutations in the gyrA or the nor $A$ gene through the following: (i) accelerating the multidrug efflux pumps (MDEPs) such as nor $A, \operatorname{sep} A$, and $\operatorname{med} A$, (ii) generating mutations at the quinolone resistance-determining regions (QRDRs) to reduce the affinity of the CFX [33]. We concluded that the $\mathrm{CFX}-\mathrm{PPh}_{3}$ derivatives have excellent antibacterial activity by inhibition of DNA gyrase and efflux pump ability. These results suggest that the $\mathrm{CFX}-\mathrm{PPh}_{3}$ derivatives could affect the delay in the acquisition of resistance more than CFX. TPP-conjugated CFX derivatives were prepared using previously published protocols (details in Supporting information) [21].

\section{Materials and Methods}

\subsection{Bacteria Strains and Culture}

All strain-related studies were conducted in certified biosafety level (BSL) facilities at the Kyung Hee University Medical Center (Seoul, Republic of Korea). All strain-related information has been listed in Table 1. Strains of drug-sensitive bacteria (control strain) were obtained from American Type Culture Collection (ATCC, Manassas, VA, USA) and Culture Collection of Antibiotic Resistant Microbes (CCARM, Seoul, Republic of Korea). Strains of drug-resistant bacteria were obtained from Asan Medical Center (ASM, Seoul, Republic of Korea). All bacterial strains were stored in skimmed milk and frozen at $-70{ }^{\circ} \mathrm{C}$. The bacterial strains were sub-cultured twice in cation-adjusted Mueller-Hinton 
broth (CA-MHB) for $24 \mathrm{~h}$ at $37^{\circ} \mathrm{C}$, prior to minimum inhibitory concentration (MIC) analysis and time or concentration-dependent study.

\subsection{Preparation of $\mathrm{CFX}-\mathrm{PPh}_{3}$ Derivatives}

TPP-conjugated CFX derivatives were prepared using previously published protocols (details in Supporting Information) [21].

\subsection{MIC Assay}

MIC was determined by using broth microdilution in CA-MHB, according to the Clinical and Laboratory Standard Institute (CLSI, 2016) guidelines [23]. In this study, we performed the MIC assay for 16 types of strains, including MDR bacteria against CFX, CFX-ester- $\mathrm{PPh}_{3}$, and CFX-amide- $\mathrm{PPh}_{3}$. Briefly, CFX and CFX-PPh ${ }_{3}$ derivatives were serially diluted (two-fold) using CA-MHB broth in a 96-well microplate. The turbidity of all strains was adjusted to a $0.5 \mathrm{McFarland}$ standard $\left(1 \times 10^{8} \mathrm{CFU} / \mathrm{mL}\right)$, $10 \mu \mathrm{L}$ of bacterial suspension was added to each well of a 96-well microplate, and the final concentration of each strain was approximately $5 \times 10^{5} \mathrm{CFU} / \mathrm{mL}$. The contents of the microplate were mixed well and incubated at $37^{\circ} \mathrm{C}$ for $20 \mathrm{~h}$. Thereafter, the lowest concentration of CFX and CFX-PPh ${ }_{3}$ derivatives, with no growth, was taken as the MIC value. For the MIC assay, the typpe strain obtained from the microorganism bank was used as the quality control strain. Each experiment was conducted in triplicate.

\subsection{Membrane-Potential Analysis}

The membrane-potential of methicillin-sensitive S. aureus (MSSA) and MRSA strains was measured by zeta-potential analysis, as reported previously by Halder et al. [34]. Briefly, all strains were grown in CA-MHB at $37^{\circ} \mathrm{C}$ overnight, $0.1 \%$ of culture media were inoculated into $3 \mathrm{~mL}$ of fresh CA-MHB, and the bacteria were cultured at $37^{\circ} \mathrm{C}$ until the density reached approximately $1 \times 10^{7} \mathrm{CFU} / \mathrm{mL}$. Thereafter, $4 \times$ MIC (Table 3 ) of CFX and CFX-derivatives were added to the culture media, which were incubated in a shaking incubator at $200 \mathrm{rpm}$ for $6 \mathrm{~h}$ at $37^{\circ} \mathrm{C}$. Subsequently, $1 \mathrm{~mL}$ of bacterial suspension was centrifuged at 13,000 rpm for $5 \mathrm{~min}$, and the supernatant was removed. The pellets were washed three times with de-ionized water $\left(\mathrm{DI} \mathrm{H}_{2} \mathrm{O}\right.$ ) and re-suspended in $1 \mathrm{~mL}$ of $\mathrm{DI} \mathrm{H}_{2} \mathrm{O}$. Finally, the bacterial suspension was diluted 10-fold in $\mathrm{DI}_{2} \mathrm{O}$ immediately prior to zeta-potential measurement. The zeta-potential of bacterial membranes was measured using Zetasizer Nano ZS90 (Malvern Instruments, Malvern, UK), equipped with a helium-neon laser $(633 \mathrm{~nm})$ as a light source, at $25{ }^{\circ} \mathrm{C}$. Each measurement was repeated three times, and all experiments were performed in two technical replicates.

\subsection{Biofilm Formation Assay}

Inhibition of biofilm formation, of 16 species of ESKAPE bacteria including MDR strains, was investigated using crystal violet staining [35]. First, all 16 types of bacterial strains were cultured in tryptic soy broth (TSB; BD Difco, product no. 211825 , Franklin Lakes, NJ, USA) at $37^{\circ} \mathrm{C}$ overnight, the culture was resuspended in fresh TSB to obtain $0.5 \mathrm{McF}$ arland turbidity. After 10-fold dilution in TSB, $200 \mu \mathrm{L}$ TSB with $0.1 \%$ glucose and $10 \mu \mathrm{L}$ bacterial suspension (approximately $5 \times 10^{5} \mathrm{CFU} /$ well) was seeded into individual wells in a flat-bottomed 96-well polystyrene microwell plate (Corning Costar, product no. 3365, Glendale, ARI. USA). To screen for anti-biofilm activity, CFX and CFX-PPh derivatives were added to the bacterial suspension in concentrations ranging from $0.5-512 \mu \mathrm{g} / \mathrm{mL}$, and the plates were incubated at $37^{\circ} \mathrm{C}$ for $24 \mathrm{~h}$. Thereafter, the culture broth and planktonic cells were removed carefully, and the wells were rinsed with phosphate-buffered saline (PBS, pH 7.4) three times and completely dried at $50^{\circ} \mathrm{C}$ for $2 \mathrm{~h}$. The dried plates were stained with $1.0 \%$ crystal violet for $10 \mathrm{~min}$ at room temperature and gently rinsed with $\mathrm{DI} \mathrm{H}_{2} \mathrm{O}$. At this point, the biofilm biomass was observed as a purple ring on the wall of each well. For quantification of the biofilm biomass, $200 \mu \mathrm{L}$ of $33 \%$ glacial acetic acid was added to each well and incubated for $20 \mathrm{~min}$ with shaking. The optical densities of the 
stained biofilm were measured at $600 \mathrm{~nm}$ using a microplate reader (Spark 10M, Tecan, Crailshim, Germany). Average absorbance for each bacterial strain was determined, and percentage inhibition of biofilm formation was calculated using Equation (1). Biofilm formation assay was performed in three biological replicates, each consisting of two technical replicates. Equation (1):

$$
\text { Inhibition }(\%)=\mathrm{OD}_{\text {Positive-control }} \text {-OD Experimental/OD Positive-control }
$$

\subsection{Time-Kill Assay}

All the strains were cultured overnight on blood agar plates, as per the standard protocol. Thereafter, the turbidity of all strains was adjusted to $0.5 \mathrm{McFarland}$ standard, and the strains were inoculated at $0.1 \%$ in CA-MHB and cultured at $37{ }^{\circ} \mathrm{C}$ for $3 \mathrm{~h}$ with shaking $(150 \mathrm{rpm})$. $\mathrm{CFX}$ and $\mathrm{CFX}-\mathrm{PPh}_{3}$ derivatives were added to the cultures when a density of approximately $10^{6} \mathrm{CFU} / \mathrm{mL}$ was reached. The concentrations of compounds used for the time-kill assay were based on MIC results (Table 3): (i) MSSA: (CFX) $0.5 \times(0.25 \mu \mathrm{g} / \mathrm{mL}), 1 \times(0.5 \mu \mathrm{g} / \mathrm{mL})$, and $2 \times(1.0 \mu \mathrm{g} / \mathrm{mL})$; $($ CFX-ester-PPh 3$) \quad 0.5 \times(11.12 \mu \mathrm{g} / \mathrm{mL}), \quad 1 \times(22.25 \mu \mathrm{g} / \mathrm{mL})$, and $2 \times(44.51 \mu \mathrm{g} / \mathrm{mL}) ;(\mathrm{CFX}$-amide-PPh 3$)$ $0.5 \times(1.39 \mu \mathrm{g} / \mathrm{mL}), 1 \times(2.78 \mu \mathrm{g} / \mathrm{mL})$, and $2 \times(5.56 \mu \mathrm{g} / \mathrm{mL})$. (ii) MRSA: (CFX) $0.5 \times(64 \mu \mathrm{g} / \mathrm{mL}), 1 \times(128 \mu \mathrm{g} / \mathrm{mL})$, and $2 \times(256 \mu \mathrm{g} / \mathrm{mL}) ; \quad\left(C F X-e s t e r-P_{3}\right) \quad 0.5 \times(5.56 \mu \mathrm{g} / \mathrm{mL}), \quad 1 \times(11.12 \mu \mathrm{g} / \mathrm{mL})$, and $2 \times(22.25 \mu \mathrm{g} / \mathrm{mL})$; $(\mathrm{CFX}$-amide-PPh 3$) 0.5 \times(1.39 \mu \mathrm{g} / \mathrm{mL}), 1 \times(2.78 \mu \mathrm{g} / \mathrm{mL})$, and $2 \times(5.56 \mu \mathrm{g} / \mathrm{mL})$. To record measurement of kill $\left(\log _{10}\right.$ scale of viable cells), samples $(10 \mu \mathrm{L})$ that were taken at each time point $(0,3$, and $6 \mathrm{~h})$ were serially diluted with sterile DI $\mathrm{H}_{2} \mathrm{O}$ and spread on drug-free Luria-Bertani (LB) plates. After a $24 \mathrm{~h}$ incubation period at $37^{\circ} \mathrm{C}$, the colonies were counted.

\subsection{Quantitative Real-Time PCR Analysis}

mRNA expression of CFX resistance-related genes (nor $A$, $\operatorname{sep} A$, and $\operatorname{mec} A)$ was measured using qRT-PCR. To obtain total RNA, MSSA and MRSA were cultured in CA-MHB with or without CFX and $\mathrm{CFX}-\mathrm{PPh}_{3}$ derivatives $(0.5 \times \mathrm{MIC})$ at $37^{\circ} \mathrm{C}$ for $24 \mathrm{~h}$ with shaking $(150 \mathrm{rpm})$. RNA was extracted using the easy-BLUE ${ }^{\mathrm{TM}}$ Total RNA Extraction kit (iNtRON Biotechnology, Republic of Korea), according to the manufacturer's instructions. Thereafter, cDNA was synthesized using the High-Capacity cDNA Reverse Transcription kit (Applied Biosystems, product no. 43-688-14, Foster, CA, USA). Applied Biosystems 7300 Real-Time PCR (Applied Biosystems, Foster, CA, USA) was used for gene expression analysis of the target genes with $2 \times$ KAPA Master mix SYBR ${ }^{\circledR}$ (Kapa Biosystems, product no. KR0389, San Francisco, CA, USA). qPCR cycling was performed at $95{ }^{\circ} \mathrm{C}$ for $10 \mathrm{~min}$, followed by 40 cycles at $95^{\circ} \mathrm{C}$ for $3 \mathrm{~s}$, and finally at $60^{\circ} \mathrm{C}$ for $30 \mathrm{~s}$. Gene-specific amplification was confirmed by the melting curve. The primer sequences used in this study have been listed in Table S1 (Supplementary Material). Data were normalized using the internal control gene, 16S rRNA, and relative mRNA expression of genes (nor $A$, sep $A$, and $m d e A$ ) was calculated using the $2^{-\Delta \Delta C t}$ method [36]. Relative gene expression analysis was repeated three times in different biological and technical experiments.

\subsection{Transmission Electron Microscopy (TEM) Imaging}

The morphological changes in MRSA ST5 5016, after treatment with CFX and CFXs-PPh derivatives, were evaluated using TEM, using a previously described method [37]. MRSA 5016 was grown in CA-MHB overnight until reaching the mid-exponential phase, diluted in fresh CA-MHB at a ratio of 1:10, and cultured for $3 \mathrm{~h}$ at $37^{\circ} \mathrm{C}$. Thereafter, MRSA (in CA-MHB) was treated with $0.5 \times \mathrm{MIC}$ of CFX, CFX-ester-PPh $\mathrm{Ph}_{3}$ and CFX-amide-PPh 3 (Table 3) for $6 \mathrm{~h}$. Subsequently, $5 \mathrm{~mL}$ of culture was centrifuged at 13,000 rpm for $5 \mathrm{~min}$, the supernatant was removed, and the cell pellets were thoroughly washed 3 times with $1 \times$ PBS. The pellets were then fixed in Karnovsky's fixative [38] at $4{ }^{\circ} \mathrm{C}$ overnight. The pellets were washed thrice with $0.05 \mathrm{M}$ sodium cacodylate buffer at $25^{\circ} \mathrm{C}$, post-fixed in $1 \%$ osmium tetroxide $\left(\mathrm{OsO}_{4}\right)$ in $0.1 \mathrm{M}$ sodium cacodylate buffer at $4{ }^{\circ} \mathrm{C}$ for $2 \mathrm{~h}$, and washed twice in sterile-distilled water at $25{ }^{\circ} \mathrm{C}$. The washed cell pellets were stained en bloc with $0.5 \%$ uranyl acetate at $4{ }^{\circ} \mathrm{C}$ overnight 
and dehydrated using highly pure ethanol $(50 \%, 70 \%, 80 \%, 90 \%$, and $100 \%)$. Finally, the pellets were treated with $100 \%$ propylene oxide for transit and polymerized with propylene oxide and Spurr's resin in a specific ratio (1:1 and 1:2, respectively). The samples were sectioned using an ultramicrotome equipped with a diamond blade and stained with $3 \%$ uranyl acetate on the grid. The stained grid was visualized using the JEM-1010 electron microscope at $80 \mathrm{kV}$.

\section{Conclusions}

In summary, we have designed TPP-conjugated CFX derivatives, which are chemically conjugated through an ester (CFX-ester- $\mathrm{PPh}_{3}$ ) or an amide bond (CFX-amide- $\mathrm{PPh}_{3}$ ), to alleviate the resistance of CFX, and investigated their antibacterial activity against multi-drug resistant bacteria ESKAPE (16 types of resistant and susceptible strains). The antibacterial activity of CFX-ester-PPh 3 and $\mathrm{CFX}$-amide- $\mathrm{PPh}_{3}$ were systematically analyzed using the MIC assay, TEM analysis, and gene expression analysis by qRT-PCR. The antibacterial activity of CFX-ester- $\mathrm{PPh}_{3}$ and $\mathrm{CFX}$-amide- $\mathrm{PPh}_{3}$ against Gram-positive bacteria, such as S. aureus (MDR S. aureus (MRSA isolates)) was excellent. In particular, the MIC values of CFX-ester-PPh $3(11.12 \mu \mathrm{g} / \mathrm{mL})$ and CFX-amide-PPh $3(2.78 \mu \mathrm{g} / \mathrm{mL})$ were significantly lower towards MRSA ST5 5016 strain than CFX alone $(128 \mu \mathrm{g} / \mathrm{mL})$. In the mode of action study, a significant morphological change of MRSA, treated with $\mathrm{CFX}$-amide- $\mathrm{PPh}_{3}$, was observed with cell membrane deformation accompanied by irregular and rough surfaces. The mRNA expression level of multi-drug pump-related genes, such as nor $A$, sep $A$, and medA, in MRSA was analyzed using qRT-PCR, and the level of these genes was observed to dramatically decrease after treatment with the CFX-PPh ${ }_{3}$ derivatives. With these promising data, we concluded that conjugation of the $\mathrm{TPP}^{+}$moiety to traditional antibiotics (CFX in this study) could enhance antibacterial activities against drug-sensitive bacteria, as well as drug-resistant bacteria. Our rationale might be simple but can have a significant impact in the field of medicinal chemistry. This work will be a foundation for the development of new types of antibiotics for the regulation of MDR bacteria. We have an ongoing project based on the piperazine site modified CFX derivatives with various chemical moieties varying in size, charge, and hydrophobicity, and the results will be reported somewhere.

Supplementary Materials: The following are available online at http://www.mdpi.com/2079-6382/9/11/758/s1, Figure S1: Minimum inhibitory concentration (MIC) assay using a 96-well plate of CFX and CFX derivatives for 16 types of MDR bacteria, Figure S2: MIC assay against Gram-negative and Gram-positive bacteria strains, Figure S3: The effect of CFX and CFX-PPh 3 derivatives on hemolysis of MSSA and MRSA, Figure S4: The cytoplasmic membrane depolarization against MSSA and MRSA by $\mathrm{CFX}$ and $\mathrm{CFX}-\mathrm{PPh}_{3}$ derivatives, Figure S5: Biofilm formation assay using crystal violet against 16 types of MDR bacteria, Figure S6: Biofilm formation assay at sub-MIC of CFX and $\mathrm{CFX}-\mathrm{PPh}_{3}$ derivatives against MSSA and MRSA, Figure S7: LB agar plate showing MSSA and MRSA CFU treated with CFX and CFX derivatives, Figure S8: Effects of CFX and CFX-PPh 3 derivatives on the expression level of gyrA gene in MSSA, Table S1: Primer list, Table S2: Biofilm formation inhibition rate at $\frac{1}{2}$ sub-MIC of CFX and CFX-PPh ${ }_{3}$ derivatives.

Author Contributions: Conceptualization, J.S.K. and D.K.; data curation, S.K., K.S., Y.J., J.K.H., K.-H.P. and J.S.K.; formal analysis, S.K., K.S. and D.K.; funding acquisition, D.K.; investigation, K.-H.P. and D.K.; project administration, K.-H.P., J.S.K. and D.K.; validation, S.K.; writing—original draft, S.K.; writing—review and editing, J.S.K. and D.K. Three authors (K.H.P., J.S.K. and D.K.) are co-corresponding authors. All authors have read and agreed to the published version of the manuscript.

Funding: This work was supported by the National Research Foundation (NRF) of Korea (Ministry of Science and ICT, NRF-2019-M3A9H1103783). This work was also supported by the Bio \& Medical Technology Development Program of the NRF of Korea (Ministry of Science and ICT, NRF-2018-M3A9H3021707) and Basic Science Research Program through the NRF of Korea (Ministry of Education, NRF-2018-R1A6A1A03025124, NRF-2018-R1D1A1B07043383). K.P. thanks the financial support received from the NRF of Korea (MSIT,NRF-2018-R1C1B5043292). J.S.K. thanks the financial support received from the NRF of Korea (CRI project, NRF-2018-R1A3B1052702). S.K. thanks the financial support received via the Global PhD fellowship (GPF) program of Korea (Ministry of Science and ICT, NRF-2014-H1A2A1020978, NRF-2019-R1A6A3A01096972).

Conflicts of Interest: The authors declare the following competing financial interest(s): the authors are listed as inventors on a pending patent application related to technology described in this work. 


\section{References}

1. Alam, M.M.; Islam, M.; Wahab, A.; Billah, M. Antimicrobial resistance crisis and combating approaches. J. Med. 2019, 20, 38-45. [CrossRef]

2. Nicolas, I.; Bordeau, V.; Bondon, A.; Baudy-Floc'h, M.; Felden, B. Novel antibiotics effective against gram-positive and-negative multi-resistant bacteria with limited resistance. PLoS Biol. 2019, 17, e3000337. [CrossRef] [PubMed]

3. Rice, L.B. Federal funding for the study of antimicrobial resistance in nosocomial pathogens: No ESKAPE. J. Infect. Dis. 2008, 197, 1079-1081. [CrossRef] [PubMed]

4. Van Duin, D.; Paterson, D.L. Multidrug-resistant bacteria in the community: Trends and lessons learned. Infect. Dis. Clin. N. Am. 2016, 30, 377-390. [CrossRef] [PubMed]

5. Vivas, R.; Barbosa, A.A.T.; Dolabela, S.S.; Jain, S. Multidrug-resistant bacteria and alternative methods to control them: An overview. Microb. Drug Resist. 2019, 25, 890-908. [CrossRef]

6. Tay, S.B.; Yew, W.S. Development of quorum-based anti-virulence therapeutics targeting Gram-negative bacterial pathogens. Int. J. Mol. Sci. 2013, 14, 16570-16599. [CrossRef]

7. Guilhelmelli, F.; Vilela, N.; Albuquerque, P.; Derengowski, L.; Silva-Pereira, I.; Kyaw, C. Antibiotic development challenges: The various mechanisms of action of antimicrobial peptides and of bacterial resistance. Front. Microbiol. 2013, 4, 353-365. [CrossRef]

8. Ghannad, M.S.; Mohammadi, A. Bacteriophage: Time to re-evaluate the potential of phage therapy as a promising agent to control multidrug-resistant bacteria. Iran. J. Basic Med. Sci. 2012, 15, 693.

9. Bassegoda, A.; Ivanova, K.; Ramon, E.; Tzanov, T. Strategies to prevent the occurrence of resistance against antibiotics by using advanced materials. Appl. Microbiol. Biot. 2018, 102, 2075-2089. [CrossRef]

10. Baker, S.J.; Payne, D.J.; Rappuoli, R.; De Gregorio, E. Technologies to address antimicrobial resistance. Proc. Natl. Acad. Sci. USA 2018, 115, 12887-12895. [CrossRef]

11. Bresolí-Obach, R.; Gispert, I.; Peña, D.G.; Boga, S.; Gulias, Ó.; Agut, M.; Vázquez, M.E.; Nonell, S. Triphenylphosphonium cation: A valuable functional group for antimicrobial photodynamic therapy. J. Biophotonics 2018, 11, e201800054.

12. Zielonka, J.; Joseph, J.; Sikora, A.; Hardy, M.; Ouari, O.; Vasquez-Vivar, J.; Cheng, G.; Lopez, M.; Kalyanaraman, B. Mitochondria-targeted triphenylphosphonium-based compounds: Syntheses, mechanisms of action, and therapeutic and diagnostic applications. Chem. Rev. 2017, 117, 10043-10120. [CrossRef]

13. Dong, L.; Neuzil, J. Targeting mitochondria as an anticancer strategy. Cancer Commun. 2019, 39, $63-65$. [CrossRef] [PubMed]

14. Khasiyatullina, N.R.; Mironov, V.F.; Voloshina, A.D.; Sapunova, A.S. Synthesis and antimicrobial properties of novel phosphonium salts bearing 1, 4-dihydroxyaryl fragment. Chem. Biodivers. 2019, 16, e1900039. [CrossRef] [PubMed]

15. Castro, W.; Navarro, M.; Biot, C. Medicinal potential of ciprofloxacin and its derivatives. Future Med. Chem. 2013, 5, 81-96. [CrossRef] [PubMed]

16. Blumberg, H.M.; Rimland, D.; Carroll, D.J.; Terry, P.; Wachsmuth, I.K. Rapid development of ciprofloxacin resistance in methicillin-susceptible and-resistant Staphylococcus aureus. J. Infect. Dis. 1991, 163, 1279-1285. [CrossRef] [PubMed]

17. Nam, Y.S.; Cho, S.Y.; Yang, H.Y.; Park, K.S.; Jang, J.-H.; Kim, Y.-T.; Jeong, J.-w.; Suh, J.-T.; Lee, H.J. Investigation of mutation distribution in DNA gyrase and topoisomerase IV genes in ciprofloxacin-non-susceptible Enterobacteriaceae isolated from blood cultures in a tertiary care university hospital in South Korea, 2005-2010. Int. J. Antimicrob. Agents 2013, 41, 126-129. [CrossRef] [PubMed]

18. Hernández, A.; Sanchez, M.B.; Martínez, J.L. Quinolone resistance: Much more than predicted. Front. Microbiol. 2011, 2, 22.

19. Pinto, T.; Banerjee, A.; Nazarov, P.A. Triphenyl phosphonium-based substances are alternatives to common antibiotics. Bull. Russ. State Med. Univ. 2018, 7, 16-25. [CrossRef]

20. Zhang, J.; Wang, Q.; Guo, Z.; Zhang, S.; Yan, C.; Tian, H.; Zhu, W.H. High-Fidelity Trapping of Spatial-Temporal Mitochondria with Rational Design of Aggregation-Induced Emission Probes. Adv. Funct. Mater. 2019, 29, 1808153. [CrossRef] 
21. Sunwoo, K.; Won, M.; Ko, K.-P.; Choi, M.; Arambula, J.F.; Chi, S.-G.; Sessler, J.L.; Verwilst, P.; Kim, J.S. Mitochondrial Relocation of a Common Synthetic Antibiotic: A Non-genotoxic Approach to Cancer Therapy. Chem 2020, 6, 1408-1419. [CrossRef]

22. CLSI. Performance Standards for Antimicrobial Susceptibility Testing; M100-S26; Clinical Lab. Standards Institute: Wayne, PA, USA, 2016.

23. Matsuzaki, K.; Sugishita, K.; Miyajima, K. Interactions of an antimicrobial peptide, magainin 2, with lipopolysaccharide-containing liposomes as a model for outer membranes of gram-negative bacteria. FEBS Lett. 1999, 449, 221-224. [CrossRef]

24. Madak, J.T.; Neamati, N. Membrane permeable lipophilic cations as mitochondrial directing groups. Curr. Top. Med. Chem. 2015, 15, 745-766. [CrossRef]

25. O'Shea, R.; Moser, H.E. Physicochemical properties of antibacterial compounds: Implications for drug discovery. J. Med. Chem. 2008, 51, 2871-2878. [CrossRef]

26. Choi, U.; Lee, C.R. Antimicrobial agents that inhibit the outer membrane assembly machines of gram-negative bacteria. J. Microbiol. Biotechnol. 2019, 29, 1-10. [CrossRef]

27. Wu, S.-C.; Yang, Z.-Q.; Liu, F.; Peng, W.-J.; Qu, S.-Q.; Li, Q.; Song, X.-B.; Zhu, K.; Shen, J.-Z. Antibacterial effect and mode of action of flavonoids from licorice against methicillin-resistant Staphylococcus aureus. Front. Microbiol. 2019, 10, 2489. [CrossRef] [PubMed]

28. Arakha, M.; Saleem, M.; Mallick, B.C.; Jha, S. The effects of interfacial potential on antimicrobial propensity of ZnO nanoparticle. Sci. Rep. 2015, 5, 9578. [CrossRef] [PubMed]

29. Trnka, J.; Elkalaf, M.; Andel, M. Lipophilic triphenylphosphonium cations inhibit mitochondrial electron transport chain and induce mitochondrial proton leak. PLoS ONE 2015, 10, e0121837. [CrossRef]

30. Sani, M.A.; Henriques, S.T.; Weber, D.; Separovic, F. Bacteria May cope differently from similar membrane damage caused by the australian tree frog antimicrobial peptide maculatin 1.1. J. Biol. Chem. 2015, 290, 19853-19862. [CrossRef] [PubMed]

31. Chang, W.; Liu, J.; Zhang, M.; Shi, H.; Zheng, S.; Jin, X.; Gao, Y.; Wang, S.; Ji, A.; Lou, H. Efflux pump-mediated resistance to antifungal compounds can be prevented by conjugation with triphenylphosphonium cation. Nat. Commun. 2018, 9, 1-12. [CrossRef]

32. Carvalho, A.R., Jr.; Martins, A.L.d.B.; Cutrim, B.d.S.; Santos, D.M.; Maia, H.S.; da Silva, M.S.M.; Zagmignan, A.; Silva, M.R.C.; Monteiro, C.d.A.; Guilhon, G.M.S.P.; et al. Betulinic acid prevents the acquisition of ciprofloxacin-mediated mutagenesis in Staphylococcus aureus. Molecules 2019, 24, 1757. [CrossRef]

33. Dong, G.; Li, J.; Chen, L.; Bi, W.; Zhang, X.; Liu, H.; Zhi, X.; Zhou, T.; Cao, J. Effects of sub-minimum inhibitory concentrations of ciprofloxacin on biofilm formation and virulence factors of Escherichia coli. Braz. J. Infect. Dis. 2019, 23, 15-21. [CrossRef] [PubMed]

34. Halder, S.; Yadav, K.K.; Sarkar, R.; Mukherjee, S.; Saha, P.; Haldar, S.; Karmakar, S.; Sen, T. Alteration of Zeta potential and membrane permeability in bacteria: A study with cationic agents. SpringerPlus 2015, 4, 1-14. [CrossRef]

35. Peeters, E.; Nelis, H.J.; Coenye, T. Comparison of multiple methods for quantification of microbial biofilms grown in microtiter plates. J. Microbiol. Methods 2008, 72, 157-165. [CrossRef]

36. Livak, K.J.; Schmittgen, T.D. Analysis of relative gene expression data using real-time quantitative PCR and the $2^{-\triangle \Delta C T}$ method. Methods 2001, 25, 402-408. [CrossRef] [PubMed]

37. Hartmann, M.; Berditsch, M.; Hawecker, J.; Ardakani, M.F.; Gerthsen, D.; Ulrich, A.S. Damage of the bacterial cell envelope by antimicrobial peptides gramicidin $\mathrm{S}$ and PGLa as revealed by transmission and scanning electron microscopy. Antimicrob. Agents Chemother. 2010, 54, 3132-3142. [CrossRef]

38. Law, B.; Bunn, W.; Hesterberg, T. Dissolution of natural mineral and man-made vitreous fibers in Karnovsky's and formalin fixatives. Inhal. Toxicol. 1991, 3, 309-321. [CrossRef]

Sample Availability: Samples of the compounds are not available from the authors.

Publisher's Note: MDPI stays neutral with regard to jurisdictional claims in published maps and institutional affiliations.

(C) 2020 by the authors. Licensee MDPI, Basel, Switzerland. This article is an open access article distributed under the terms and conditions of the Creative Commons Attribution (CC BY) license (http://creativecommons.org/licenses/by/4.0/). 